MORE THAN A FEELING?: TOWARD A THEORY OF CUSTOMER DELIGHT

\begin{tabular}{|r|l|}
\hline Journal: & Journal of Service Management \\
\hline Manuscript ID & JOSM-03-2019-0094.R1 \\
\hline Manuscript Type: & Research Paper \\
\hline Keywords: & customer delight, Customer behavior, Customer Satisfaction \\
\hline \multicolumn{2}{|l}{} \\
\hline
\end{tabular}

SCHOLARONE $^{\text {TH }}$
Manuscripts 


\title{
MORE THAN A FEELING? \\ TOWARD A THEORY OF CUSTOMER DELIGHT
}

\begin{abstract}
Purpose:

Responding to an increasing call for a more comprehensive conceptualization of customer delight, the purpose of this paper is to expand the theory of customer delight and to examine the implications of such an expanded view for service theory and practice.

\section{Design/methodology/approach:}

This paper presents the results of three qualitative studies. The first study explores customer delight through self-reported consumption experiences in customer-selected contexts, followed by one-on-one in-depth interviews. The second involves focus groups and the third examines self-reported incidents of delightful customer experiences.
\end{abstract}

\section{Findings:}

This research finds that customer delight goes beyond extreme satisfaction and joy and surprise to include six properties that - individually or in combination - characterize customer delight. An expanded conceptualization of how customer delight can be defined is proposed in which customer delight is associated with various combinations of six properties -- the customer experiencing positive emotions, interacting with others, successful problem-solving, engaging customer's senses, timing of the events and sense of control that characterizes the customer's encounter.

\section{Research limitations/implications}

It is clear from the findings of this research that there is no single property that is associated with delight. Through the facilitation of multiple properties, managers have the 
potential to create a multitude of routes to delight. It is recommended that future research (1) identify and explicate these alternative routes for engendering delight using the six properties identified, and (2) develop a general typology based on service context and characteristics, customer segment, etc. that further stimulates scholarship on delight, and offers more industryspecific insights for managers.

\section{Practical implications}

Insights from this investigation will encourage managers and service designers to think more broadly and creatively about delight. Doing so will open up new opportunities for achieving customer delight, beyond merely focusing on extreme satisfaction or surprise and joy strategies currently dominating discussions of customer delight.

\section{Originality/value}

This paper makes several contributions to the service literature. First, it extends current conceptualizations of customer delight and offers an expanded definition. Next, it demonstrates how this new understanding extends the existing literature on delight. Finally, it proposes an agenda for future delight research and discusses managerial implications, opening up new opportunities for firms to design delightful customer experiences. 


\section{INTRODUCTION}

Managers commonly believe that customer satisfaction is a fundamental determinant of long-term consumer behavior. This widespread acceptance has made customer satisfaction the most widely used metric in the measurement and management of consumer loyalty (Aksoy, 2013). As a result, companies spend substantial amounts of money to measure and manage customer satisfaction. The academic literature also points to a positive relationship between customer satisfaction and desirable business outcomes such as increased customer retention, revenue, and stock market performance (Anderson and Mittal 2000; Heskett, Sasser and Schlesinger 1997; Parasuraman, Zeithaml and Berry 1988; Parasuraman, Zeithaml and Berry 1985; Rust and Zahorik 1993; Rust, Zahorik and Keiningham 1995). This relationship however tends to be weak (Keiningham et al. 2014; 2003) and varies greatly by industry (Larivière et al. 2016).

Therefore, as firms continue to vie for the attention and loyalty of increasingly savvy and well-informed customers, designing experiences that delight rather than merely satisfy has emerged as a business imperative (Andreassen et al. 2016; Vanhamme 2008; St-James and Taylor 2004). When compared to satisfied customers, delighted customers report higher levels of loyalty, commitment and repurchase (see Barnes et al. 2016; Barnes et al. 2010). Given increasing evidence that "mere" customer satisfaction (i.e., the absence of dissatisfaction) does not necessarily inspire loyalty (Jones and Sasser 1995), delighting customers is seen as a way to prevent them from switching (Barnes et al. 2013). The popular business press is filled with anecdotes and case studies touting the importance of pursuing a delight strategy.

The question of what delight is and how to measure it as a metric however is not without challenges. Indeed, critical questions regarding the construct have yet to be addressed 
effectively (Barnes and Krallman 2019). For instance, while some studies describe delight as a combination of joy and surprise (e.g., Arnold et al. 2005; Finn 2005), others argue surprise is not always necessary to achieve delight (Kumar, Olshavsky and King 2001). Still others consider delight to be an extreme form of satisfaction (e.g., Estelami 2000, Keiningham et al. 1999), a perspective at odds with those who argue that delight is distinct from satisfaction (Finn 2012). As summarized in Table 1, much of the research on delight to date has used different conceptualizations, proposed various determinants of delightful experiences and differing measures for the construct.

This paper responds to an increasing call for a more comprehensive theory of the delight construct that goes beyond extreme satisfaction (Parasuraman 2013) and joy and surprise and examines two research questions that contribute to the literature.

1) What is customer delight? Is there a single dimension sufficient to define customer delight? Or are there multiple dimensions of delight?

2) If customer delight has multiple dimensions, which dimension or combination of dimensions are associated with delight?

The paper is structured as follows. We begin with a synthesis of theory and research on delight from the marketing, consumer behavior and psychology literatures. We then describe three qualitative studies and discuss findings from them. We conclude with a discussion, managerial implications and a research agenda stemming from our overall findings.

\section{THEORETICAL BACKGROUND}

\section{Customer Delight: Emotion and Surprise}


Customer delight is typically described in the marketing and consumer behavior literature as a positive emotion that people experience in response to having their expectations exceeded to an unanticipated and surprising degree (Oliver, Rust and Varki 1997).

Conceptualizations of customer delight as an emotional or affective response to customer experience (Arnold et al. 2005; Finn 2005; Oliver, Rust and Varki 1997; St-James and Taylor 2004; Verma 2003) originate from the emotion literature with an emphasis on Plutchik's (1980) model of primary emotions.

In the case of delight, extreme positive emotions are described as a combination of joy and surprise (Rust and Oliver 2000; Valenzuela et al. 2010), a perspective that is rooted in a view of delight as a secondary emotion stemming from the convergence of two primary emotions: surprise and joy (Plutchik 1980). A critical incident study by Arnold et al. (2005) aligns with this approach to delight. In that study, respondents were asked to describe an experience that they could remember that is absolutely, positively delightful, where delight was explicitly described to the shopper as feelings of both joy or happiness, and surprise (see Table 1). In a study of hedonic (restaurant) and utilitarian (auto) services, Kim and Mattila (2013) describe customer delight as a response to a pleasant surprise combining surprise and joy. Other researchers (e.g., Verma 2003) make similar observations. A scale developed by Finn (2005) and used by others (Bartl, Gouthier and Lenker 2013) conceptualizes delight as an emotional response resulting from surprisingly positive performance, and measures the construct using emotion descriptors such as delighted, elated and gleeful. Wang (2011), utilizing Finn's (2005) approach to operationalize delight, includes arousal and other emotions such as happy, contented and pleased among the measures. The inclusion of arousal in describing delight in a consumption context is also discussed by Oliver, Rust and Varki (1997) and used in other 
studies as well (Loureiro 2010; Loureiro, Correia and Ribiero 2014; Magnini, Crotts and Zehrer 2011). This is likely because the emotion of delight appears in the highly aroused section of positive affect in circumplex models and as such is included in the Surprising Consumption $\rightarrow$ Arousal $\rightarrow$ Delight sequence proposed by Oliver (2010).

\section{*** INSERT TABLE 1 AROUND HERE ***}

Other research suggests that different types of joy can also result in delight with or without the involvement of surprise, e.g., "magic" joy that comes from a short-lived experience that a person feels is a result of good luck or fate versus effort and "real" joy (Kumar, Olshavsky and King 2001) that is based on an activity which triggers a feeling of relatedness between a person and the firm and that results from one's effort. St-James and Taylor (2004) propose a similar "delight-as-magic" emotional arousal description for certain consumption experiences that are subjective, and have symbolic meaning associated with themes of interpersonal warmth, aesthetic experiences, or leisure experiences.

More recently, Ball and Barnes (2016) argue that, in addition to joy and surprise, gratitude may also lead to delight and that recent advances in the study of positive psychology (see Seligman and Csikszentmihalyi 2014) may open routes to a broader conceptualization of delight involving more positive emotions than simply joy and surprise.

\section{Customer Delight: Extreme Form of Satisfaction?}

Another widespread conceptualization of delight, quite different from the ones described earlier, treats the construct as an extreme form of satisfaction (rather than as a distinct construct). Researchers who share this perspective define the construct as the upper end of a satisfaction continuum (Berman 2005; Kumar and Iyer 2001; Ngobo 1999). This is illustrated by a scale developed by Westbrook (1980), with scale labels ranging from "neither satisfied/nor 
unsatisfied" to "delighted", with an intermediary degree of "mostly satisfied." Using such an approach to measure delight typically involves asking respondents for their satisfaction ratings and then classifying those with the highest satisfaction scores as being delighted (e.g., Estelami 2000).

The aforementioned approach to operationalizing delight has its roots in the expectations-disconfirmation paradigm, which posits that the degree of satisfaction/dissatisfaction depends on the nature and extent of the discrepancy between customer expectations and perceptions (Oliver 2010). It is also consistent with the notion of a customer's "zone of tolerance" (Parasuraman, Berry and Zeithaml 1991; Zeithaml, Berry and Parasuraman 1993), which represents a range of service expectations bounded by adequate and desired service levels, thereby implying that customer perceptions falling below, within or above the zone of tolerance would lead to dissatisfaction, satisfaction or delight, respectively. Nevertheless, this approach still leaves ambiguous the issue of whether delight is distinct from or merely an "extreme" form of - satisfaction.

\section{Customer Delight: Distinct from Satisfaction?}

Some studies raise questions about treating delight simply as very high levels of satisfaction (Finn 2012; Kumar and Iyer 2001; Oliver, Rust and Varki 1997; Rust, Zahorik and Keiningham 1995; Verma 2003). For instance, Oliver, Rust and Varki (1997) argue that delight is qualitatively different from satisfaction. Rust, Zahorik and Keiningham (1994) and Barnes, Ponder and Dugar (2011) find that the drivers of satisfaction and the drivers of delight are not the same. Similarly, Kumar and Iyer (2001) find that aspects related to a service provider's interpersonal behavior discriminate better between satisfaction and delight than do aspects related to the firm's service characteristics. In addition, Finn (2012) finds that satisfaction and 
delight exert separate effects on behavioral intentions. Berman (2005) notes that delight requires out-of-the-ordinary service or product performances and proposes that delightful experiences are more memorable than satisfying experiences and hence are likely to be more strongly etched in consumers' memories. Along similar lines, Schneider and Bowen (1999) and Kano et al. (1984) distinguish between attributes that are "potential delighters" versus "must-have" attributes.

As this review of the literature reveals, there is currently no agreed upon universal theory of what constitutes customer delight. This is exacerbated by disparate approaches to measuring delight (see Table 1). Many studies use the critical incident technique, with some specifying to the respondent what a delightful experience is (Arnold et al. 2005) and others leaving it open ended (Barnes et al. 2013; Swanson and Davis 2012; Verma 2003). Other studies utilize multi-item scales (albeit with different items) (e.g., Bartl, Gouthier and Lenker 2013; Crotts et al. 2008; Finn 2005; Kim and Mattila 2013; Kumar, Olshavsky and King 2001; Loureiro 2010; Loureiro and Ribeiro 2014; Wang 2011), and still others use a single item overall delight measure (e.g., Chitturi, Raghunathan and Mahajan 2008) or mathematical models of customer delight (Rust and Oliver 2000).

In summary, previous research and extant literature on customer delight, while extensive, collectively raise important issues pertaining to the conceptualization of delightful experience from the customer perspective. To provide insight, this research undertakes an indepth investigation designed to answer the following questions:

1) What is customer delight? Is there a single dimension sufficient to define customer delight? Or are there multiple dimensions of delight?

2) If customer delight has multiple dimensions, which dimension or combination of dimensions are associated with delight? 


\section{RESEARCH METHODOLOGY AND FINDINGS}

Recognizing that a single method for gathering qualitative data is rarely adequate to shed ample light on a phenomenon (Creswell 2013), we gathered data from 249 customers across three studies using four distinct methods (consumption diaries, in-depth one-on-one interviews, focus groups, qualitative survey) to generate rich data and triangulate insights across time, participants and contexts. We describe our research design in two parts. First, we describe two exploratory studies (Study 1 and Study 2) designed to better understand delight as it relates to perceptions of customer experience. Next, we describe Study 3, a qualitative survey of 200 people informed by insights from our 2 exploratory studies.

\section{Study 1}

The goal of Study 1 was to understand how customers experience delight through the lens of their day-to-day consumption experiences. This qualitative study consisted of an exploration of consumption diaries and in-depth interviews. Consumers were recruited by telephone and through acquaintances, colleagues and participant recommendations. Given the ubiquity of consumption activities and the exploratory nature of this phase of our discovery, we connected with potential participants using a purposive snowball sampling technique to locate key informants and critical cases that would result in information-rich data (Patton 2002). A sample size of five customers was deemed to be appropriate to launch Study 1, as the sufficiency of sample size in qualitative research is measured by the depth of data generated over frequencies (O'Reilly and Parker 2013). The combined use of consumption diaries and indepth interviews in Study 1 generated a rich preliminary data set.

Participants who expressed initial interest in the study were provided with a formal survey invitation along with instructions. The survey prompted potential participants to either 
opt in and provide demographic information or opt out. Based on personal information provided by the participants: (a) four were women; (b) three were white/Caucasian, one was African American, and one was Hispanic; (c) three were married; their ages ranged from the 20s to the 50s; and (d) their annual incomes ranged from below $\$ 25,000$ to over $\$ 200,000$.

Participants were offered $\$ 50$ to complete two tasks: 1) describe their daily consumption experiences in an online diary for one week and 2) complete a one-on-one follow-up interview via telephone or video-conference during the following week. Three options for recording and transmitting their consumption experiences were offered to participants: 1) an online portal created for the task, 2) email, or 3) a conventional paper diary. All chose to use the online portal.

For the consumption diaries, participants were instructed to employ all resources at their disposal including written descriptions, photos, videos, audio or collected tangible artifacts to capture/record their consumption experiences that delighted them (see Appendix). Daily email reminders containing links to the online portal were sent to participants each morning during the seven-day study period to encourage maximum engagement. The online portal was checked by members of the research team daily to ensure that the data gathering process was working properly. At the end of the week, responses from each participant were reviewed and catalogued.

The week following the completion of consumption diaries, one-on-one in-depth interviews were conducted with participants via telephone and videoconference. All interviews were audio-recorded and transcribed. In the interviews, lasting between 60 and 90 minutes, participants were asked to: 1) describe each delightful experience listed in their consumption diary in their own words, 2) elaborate on how/why each experience engendered delight, 3) 
describe outcomes of the experience and post-experience intentions related to sharing with others and their intent to return, 4) provide single words or short phrases to describe each individual experience and, 5) speculate, based upon their experience, how they might define customer delight without being prompted with a description of the concept. Open-ended questions to clarify concepts and experiences helped to guide the conversations.

\section{Study 2}

The goal of Study 2 was to augment data collected in Study 1 and to develop a deeper understanding of delight. A new group of consumers was identified to participate in a focus group using a snowball sampling technique. Fifteen adults were selected purposively to ensure sufficient heterogeneity across gender, race, ethnicity and age. Participants were informed that they would be part of a study of consumer behavior and would be paid $\$ 10$ to participate in a single focus group lasting approximately one hour. Sessions were conducted in a suburb of New York City in the United States.

When they arrived at the site, participants were offered refreshments and administered a short, written survey to: 1) collect demographic and contact information; 2) task the participant with recalling a time when they had an experience that delighted them and 3) provide a stepping off point for the focus group conversations. They were also informed that the focus group would be videotaped and recorded so it could be viewed and transcribed. The researcher then asked them if they would like to share with the group the details of the experiences they wrote down on the survey. In each of the focus groups, volunteers stepped up quickly, leading to effortless and fruitful discussions. To minimize bias, the researcher acted primarily as a silent observer, interjecting only when necessary to ask a clarifying question or to move the conversation forward. Each focus group lasted longer than 60 minutes. Participants were very 
engaged in the study topic and continued to have lively conversations about it even after the conclusion of the formal group sessions.

\section{Studies 1 and 2: Data Analysis and Findings}

Following Batra, Ahuvia and Bagozzi (2012) and to have a second order of triangulation of the data, consumption diaries and interview transcripts from Study 1 and focus group transcripts from Study 2 were reviewed manually by researchers as a single data set. Guided by Braun and Clarke (2006) the researchers: 1) read and re-read transcripts to note preliminary ideas, 2) generated initial codes across the data set, 3) searched for initial themes, 4) reviewed and mapped themes, 5) defined and named themes and 6) reported preliminary themes. Two independent coders, both of whom have experience with qualitative analysis, were then asked to review the data, codes, themes and report to ensure rigor in the analysis. This review yielded insights into the manner in which customers perceive and characterize their consumption experiences.

Insights and themes were then classified into categories using an iterative process guided by theory (Spiggle 1994). Categories were compared and contrasted within and across conditions: first within Studies 1 and 2 separately, and then between studies, until all data was considered and no new interpretations emerged. Six distinct dimensions of delight-related customer experience emerged from our analysis within and across Studies 1 and 2: Emotions, Interpersonal, Problem-solving, Senses, Timing and Control. We describe these dimensions, which we refer to as "properties of customer delight," in the following sections.

Additionally, we present the proposed delight properties in Table 2 accompanied by representative excerpts from the data gathered in Studies 1 and 2 and three columns indicating where joy, surprise and other drivers of delight are evident. Given space constraints and the 
conversational nature of participant descriptions of their experiences, some excerpts have been edited for brevity and clarity. In such instances, care has been taken to retain meaning, emotion and tone.

*** INSERT TABLE 2 AROUND HERE ***

Additionally, the quotes, concepts and insights referenced in the following sections are illustrative of relevant observations. They represent and provide robust support for the properties that are evident throughout the dataset, which is available in its entirety from the authors for review.

\section{Property 1 "Emotions": Customer delight involves positively valenced emotions.}

Customer observations of positive emotional valence, and high and low arousal, surfaced in the study. Regarding customer delight in particular, participant descriptions reference familiar characteristics from existing literature such as joy (with or without surprise), awe/magic and other positively valenced emotional states. There are, however, indications of a greater breadth of emotional states that correspond with customer-reported delight, such as contentment, peace, relief, and sense of achievement, that are evident but less discussed in existing delight-related literature (see Wang 2011; Finn 2005; Kwortnik and Ross 2007; Soscia 2007). These specifically include higher arousal emotions such as happy, contented and pleased as well among extant measures of delight (Bartl, Gouthier and Lenker 2013; Finn 2005). The inclusion of arousal in describing delight in a consumption context is in line with the findings of Oliver, Rust and Varki (1997).

Moreover, participants were quite candid about how the emotions that precede consumption experience influenced their encounters with service providers. For example how a good mood helped them to be more patient with a service provider and overall how the 
emotions they brought to the exchange and the subsequent response of the service provider significantly influenced their perceptions of service experiences.

Surprisingly, although the predominant emotions experienced were positive ones, a few participants described delight experiences in which their emotional state was negatively valenced. These mixed-emotion scenarios (Ruth et al. 2002) suggest that consumer perception of emotions related to service experience is complex and sometimes non-linear in terms of valence. For example, one participant described meeting a friend who was moving away for coffee as a delightful experience despite the sadness associated with the situation. Although such situations are not unprecedented in consumer behavior research (see Goldsmith et al. 2012), they are currently absent from the delight literature.

\section{Property 2 "Interpersonal": Customer delight emerges from interpersonal interactions.}

Participants reported that interactions with service providers and other marketplace actors influenced their perceptions of experiences. This is in keeping with extant literature that explores the influence of marketplace employees (Bowen 2016; Del Court et al. 2016) and other customers (Colm et al. 2017) on customer behavior. For instance, participants valued respect - and condemned disrespect - during employee-to-employee, employee-to-customer and customer-to-customer interactions. This includes behavior experienced by the customer directly (e.g., a friendly/rude service provider or helpful/difficult fellow customer) or indirectly (e.g., a customer observing a manager/fellow customer being friendly/rude to another customer or an employee). Sincerity, authenticity, thoughtfulness or human connection also influences assessment of delight experiences.

As one might expect, positive interpersonal experiences tend to be associated with positive assessments (i.e., delight and satisfaction). This, however, is not universally observed 
in our data. In some cases, interpersonal factors can have a mixed influence on overall customer experience (e.g., great service overcoming mediocre coffee at the coffee shop, or the experience of a great meal at a fine-dining restaurant being tainted by inattentive wait staff).

It is interesting to note that interpersonal interactions that influence customer perceptions of their experience does not require direct interaction. Our data reveals instances in which interactions between employees and their managers or other customers also influenced participants' assessments. Indeed, whether as a source of empathy for a service provider or a justification for critique, having experience "in the shoes" of a service provider influences the assessment of the current experience. These observations are in keeping with insights from emerging research on the effects of customer co-presence on consumer experiences (Colm et al. 2017).

\section{Property 3 “Problem-Solving”: Customer delight emerges from problem-solving during and} encounter.

In describing their consumption experiences and assessments, some study participants alluded to functional aspects pertaining to met goals and objectives. These participants focused less upon service expectations and more on whether or not the problems or issues they brought to or experienced during an encounter were resolved. Problem-solving as a potential path to delight is found in the popular literature (Ireland 2011), but has been less frequently investigated. One exception is the earlier research by Grönroos (1988) and a more recent example is the emerging "jobs to be done" theory (see Christensen et al. 2016).

Participants reported experiencing delight when they faced challenges, had unique needs, or encountered service failures, and the service provider addressed their issues/needs. In the case of one restaurant patron, for instance, a chef attempting to recreate a favorite food item 
that was no longer available produced customer delight, even though the resulting dish was not as good as the original. In that case, even an attempt to solve a customer problem was viewed as delightful. It is noteworthy that this and many other examples in our data come from seemingly utilitarian service environments (e.g., car repair, furniture delivery, cable television service), suggesting that focusing on functional aspects may lead to delight even in non-hedonic service settings.

\section{Property 4 "Senses": Customer delight can be triggered through various senses.}

In keeping with extant servicescape literature (Bitner 1992), our data suggest that sensory experiences influence assessment of delight and related constructs. Sights, sounds, flavors, textures and odors influence how customers experience services. Participants reflected on flavors and fragrances (enjoyable or off-putting) in ways that evoke memories of past encounters and generate rich and detailed descriptions suggesting that there is a link between nostalgia and delightful experiences.

In some cases, participants struggled to find words to describe the results of their sensory experiences, resorting instead to comparisons and metaphors to clarify their sense of delight and related constructs. These less concrete descriptions illustrate that it is sometimes difficult for the customer to characterize the specific drivers of delightful sensory experiences, but they recognize them as such.

\section{Property 5 "Timing": Customer delight can be instantaneous or can emerge from a prolonged sequence of events.}

The importance of time as an assessment variable is evident and is described in a variety of ways among and within the experiences of participants. This is not surprising, since recent research suggests that temporal perspectives influence experience across the customer 
journey (see Lemon and Verhoef 2016; DeKeyser et al. 2015) before, during and after service encounters (see Maguire and Geiger 2015).

In the case of individual service encounters, participants appear to assess the focus and attention of service providers based upon their schedules and the nature of the service encounter. For example, one participant described two time-related encounters that happened in the same day as delightful—one that went quickly and the other that was prolonged. In the first, which took place in the morning on her way out to run a number of errands, she was delighted to get in and out of her favorite coffee shop quickly to start her day. She then recounted her delight when a salesperson took his time to describe a product in detail when she had more time to complete the service encounter.

Overall, there does not appear to be a consistent relationship between individual preferences and temporal assessment. Instead, the desire for speedy or leisurely service appears to depend upon customer needs/desires at the time of the service encounter. That said, some patterns among industries appeared that may be interesting to study further. For instance, while study participants in healthcare settings want to be called in to see the doctor promptly, they report that they do not wish to be rushed during the actual visit with a doctor, especially when the time is spent sharing information or developing a closer relationship.

\section{Property 6 "Control": Customer delight is triggered by perceived control.}

A desire for some control or role in shaping service experiences - to help create positive experiences and to turn around negative experiences when problems arise -is a finding consistent with the link between consumer power and behavior discussed in extant literature (e.g., Denegri-Knott et al. 2006). 
Our findings suggest that having choices or even just assisting service providers in devising a mutually acceptable solution to a service challenge, perhaps by using principles of distributive, procedural and interactional justice (Blodgett, Hill and Tax 1997) can lead customers to delight. Participant stories suggest that co-creation of mutual value through collaboration may be another route to customer delight. This desire for participation or control was described frequently in online or telephone encounters, especially those where participants were put on hold or forced to engage with a form or electronic system in which they perceive themselves to be lost or trapped.

\section{Study 3:}

Findings from Studies 1 and 2 demonstrate that customer delight has 6 properties associated with it. The question that remains unanswered is whether these properties are formative in which a single property is sufficient for delight or whether it is reflective wherein multiple properties are needed to trigger delight. In order to answer this question and further explore how the properties of delight may work separately or in tandem, a final Critical Incident Technique (CIT) survey-based study (Study 3) was undertaken and the data analyzed using both human coding and text mining via machine learning (e.g., Ordenes et al. 2014 and McColl-Kennedy et al. 2019). This study provides the added benefit of determining whether the results of Study 1 and 2 replicate with a different sample. The CIT study collected data through a survey by asking 200 respondents to report their reflections on customer delight. CIT is a method frequently used in service research that relies on a set of procedures to collect, content analyze, and classify observations of human behavior related to a specific situation or context (Gremler 2004). The sample of 200 respondents was heterogeneous across gender (50\% male, 50\% female), age (range 21 to $65+$ ), ethnicity 
(68.5\% Caucasian, 12\% African American, 5.5\% Asian American, 12\% Hispanic and 2\% other) and income (evenly distributed from $<\$ 15,000$ to $>\$ 200,000$ per year). First, the 200 responses were analyzed manually by two human coders. Next, the two coders independently developed an initial coding schema to facilitate mapping key words, phrases and sentences to the six properties that emerged from Studies 1 and 2. The coders then compared and contrasted their independent schemas and agreed upon a single coding schema. The inter-rater reliability was .93, well above the accepted level (Rust and Cooil 1994). In cases where there was disagreement, the two trained coders discussed their coding with a third person (one of the authors), who acted as a judge until a decision was reached (Brady, Voorhees and Brusco 2012). The third step involved developing linguistic rules in IBM SPSS Modeler to automatically classify words and sentences using the coding schema developed in step 2 (Humphreys and Wang 2018). The 200 descriptions of delightful experiences were then imported into IBM SPSS Modeler and linguistic rules were applied to automate the process and automatically map the responses to the six properties of delight. The final step was to validate the software output in which researchers manually checked each comment to identify whether the software mapped the comments correctly to the relevant delight properties. The results indicate that the comments successfully mapped onto the six properties of delight thus providing additional validity to the findings of Study 1 and 2 (See Table 3).

*** INSERT TABLE 3 AROUND HERE ***

\section{TOWARDS A THEORY OF CUSTOMER DELIGHT}

The following section highlights the main areas of contribution of the research vis-a-vis the delight literature and where it aligns with, diverges from, or enhances knowledge in this area. 


\section{There are six properties associated with customer delight, not just one or two.}

As noted earlier, most conceptualizations of the delight construct in the extant literature describe it in one of two ways. One conceptualization focuses on experiencing joy. The other focuses on surprisingly positive firm-customer encounters. The results of this investigation support these conceptualizations.

This research also finds however, that delight-creating customer experiences are often the result of the inclusion of multiple dimensions: specifically, six distinct properties. Achieving customer delight generally involves positively valenced emotions, interactions with other customers and employees, successfully solving the customer's problem during the service encounter, linking the experience to nostalgia and engaging various senses, a range of duration including quick versus prolonged timing, and finally a customer feeling a sense of control/agency.

2. Typically customer delight is associated with the combination of three or more properties.

This investigation finds that the six properties associated with customer delight rarely operate independently and as such does not follow a formative process. This suggests that through different combinations of these properties, many examples of delight can emerge. The following excerpt from our data provides an example of one participant using multiple properties to describe a trip to the grocery store with her daughter:

"I like that it is small (senses). The sales people are always super nice (interpersonal). Mia seems to think it's an amusement park ride, because she rides in the cart and everyone says hi to her (interpersonal)....You know I can kind of get in and out really quickly (timing) it is only like four aisles or five aisles..."

This investigation demonstrates that customer delight is almost never associated with a single property. In fact, we find that in less than three percent of the time does delight have fewer 
than two properties. Instead, customer delight is associated with the combination of three or more properties over seventy percent of the time (70.9\%) (see Figure 1). Therefore, there is evidence that positive experiences delivered through some combination of these six properties provide the greatest likelihood that the customer experience will be perceived as delightful.

\section{*** INSERT FIGURE 1 AROUND HERE ***}

\section{There is a trinity of properties that currently lead all others.}

Although six distinct properties are associated with customer delight, three propertiesemotions, interpersonal, and problem-solving — are much more frequently recalled by customers regarding experiences that delighted them (see Figure 2). Specifically, this investigation finds that $58.2 \%$ of all delight experiences contained all three of these properties. Therefore, there is evidence that the highest probability of customer delight is the combination of positively valenced emotions, interpersonal experiences, and customers' perceptions that the "job to be done" is handled effectively. While this combination of ingredients appears logical, it is noticeably absent from the current literature on customer delight.

\section{*** INSERT FIGURE 2 AROUND HERE ***}

Moreover, there are several important nuances in these findings that distinguish them from the current literature on delight. First, as noted earlier, the emotions experienced can be much broader than the traditional joy and surprise elements found in much of the literature on customer delight. Second, the interpersonal nature of most delight experiences suggests that delight is a function of shared experiences. This aligns strongly with current thinking on customer experience where social elements are proposed to play a role in customers' perceptions of their experiences (De Keyser et al. 2015; Bolton et al. 2018). Also, this aligns 
with much of the research on happiness, where shared experiences are found to be strong predictors of human happiness (e.g. Gilbert 2006).

It should be noted, however, that although the majority of time there are currently three properties most commonly associated with customer delight, the lack of prominence of the other three properties may be a function of current company offerings rather than an indication of their relative lack of importance. Without question, timing and engaging various senses play important roles in situations as diverse as restaurants, theme parks, and movies. Moreover, ambient conditions such as scents, music, and color are often deliberately designed to affect the subconscious (while remaining in the background) to impact customers' perceptions and emotional responses through subconscious triggers (Soars 2009; Wirtz and Lovelock 2016). Therefore, as more establishments emphasize experiences - as is the case for brick and mortar retailers in their efforts to compete with online retailers (e.g., Foxman 2018) — these less frequently recalled properties may take on greater frequency and prominence in the future.

In summary, this enhanced perspective better recognizes the complexity of customer assessments of service experiences. Moreover, it acknowledges that delightful customer experiences can be an aggregation of multiple delight properties that hold more or less weight with the customer in different circumstances, or even within the same service encounter. As a result, an expanded conceptualization of how customer delight can be defined is proposed below:

Customer delight is associated with various combinations of six properties including the customer experiencing positive emotions, interacting with others, successful problemsolving, engaging customer's senses, timing of the events and sense of control that characterize the customer's encounter. 
The following sections discuss the managerial implications of these insights and provide an agenda for future research.

\section{MANAGERIAL IMPLICATIONS}

The expanded conceptualization of customer delight resulting from this investigation offers managers a new way (1) to think systematically and holistically about how their customers might evaluate various interactions within the specific context of their firm and (2) to identify potential opportunities for delighting customers during those interactions that are aligned with the goals and objectives of both the customer and the firm. The aforementioned recommendation of conducting a more systematic and holistic examination of their customers' experience-assessment process might reveal to managers which properties of delight emerge for various customer segments, how the company fares when it comes to engendering these properties and overall generating fresh ideas for creating delight that go beyond "wowing" their customers or satisfying them to a high degree.

One of the most important lessons for managers resulting from this investigation is that delight creating efforts need to address three properties simultaneously-most typically existence of positive emotions, interpersonal interactions, and successful problem-solving - to increase the likelihood that these endeavors will achieve the desired outcome. Table 4 shows how each property identified in our investigation tends to co-exist with other properties in delight-creating experiences. While engendering other properties may seem to add to the difficulty, it actually increases the opportunity for managers to take tangible actions.

Managers in some organizations, however, have begun to explicitly recognize the need to design products for delight creation. For example, Intuit has adopted and branded a "Design for Delight" strategy to help ensure that its products and services delight customers (Smith 2015). 
This investigation offers support that managers should adopt a formal human-centered service design process to enhance their offerings and guide their innovation efforts to increase the likelihood that their efforts will engender customer delight (e.g., Cook et al. 2002; Field et al. 2018).

\section{*** INSERT TABLE 4 AROUND HERE ***}

First, the prominence of the problem-solving property in this investigation makes clear the imperative of knowing and successfully addressing what problem the customer has come to the firm to solve. While the problem-solving property corresponds closely to the Reliability dimension in SERVQUAL (Zeithaml, Parasuraman, and Berry 1990), much of the emphasis in the current academic and management literature on delight corresponds to how the service is performed (e.g. friendliness, rudeness, sloppiness, etc.) and aspects of the service recovery journey (Van Vaerenbergh et al., 2019).

Second, the prominence of the Interpersonal property in this investigation makes clear that customer delight is frequently the result of shared experiences. The psychology literature consistently shows that human happiness is strongly related to connections with others (e.g., Gilbert 2006). Clearly, managers can foster positive employee-customer interactions (discussed in more detail later). The SERVQUAL dimensions of Responsiveness, Assurance, and Empathy directly relate to these employee-customer interactions (Zeithaml, Parasuraman, and Berry 1990). In fact, customers' interactions and communications with strong ties (e.g., friends and family), as well as weak ties (e.g., online connections) (Keiningham et al. 2018) have the potential to impact attitudes and behaviors often to a stronger degree than do employee-customer interactions. Therefore, wherever reasonable, managers should facilitate the ability of customers to either share positive experiences with others as they occur, or make it easier for customers to 
communicate information about their positive experiences with others as an integral part of the offering. Where possible, this should occur as part of the entire customer journey (Edelman and Singer 2015). For example, the L'Oréal Makeup Genius app not only allows customers to explore new products prior to purchase, but also to share how the customer would look using different makeup products with friends — or with many—-to get feedback and to join in the trial and purchase experience (L'Oréal Paris USA, 2014).

Third, managers should consider broadening the emotional states that they seek to induce in customers from the surprisingly positive "wow" moments to include other delight-related emotions such as contentment, peace, relief, and sense of achievement. The most relevant delight-related emotions will likely vary by the context in which the customer interacts with the firm. Nonetheless, different contexts in which customers typically engage the firm can be identified through standard research techniques (e.g., anthropological research, neuroscience, behavioral economics, etc.). Since the most relevant emotions will likely differ significantly by industry, firm, and even products/services offered within a firm, generalizations about specific emotions are not likely to be robust. But an understanding of customers' desired emotional states when interacting with the firm can impact human-centered service design efforts to engender customer delight.

Fourth, managers must recognize that experiencing various senses, timing of delivery, and feeling a sense of control can help induce delight in some customers. It is important to note that it is likely that some of these properties play a more prominent role than identified by customers, but because several of these properties (perhaps all) often work on a subconscious level they are not obvious to customers in their recall of delightful experiences. Nonetheless, when they are recalled, it is typically in conjunction with the three most mentioned properties: 
experienced emotions, interpersonal interactions, and successful problem-solving. Therefore, these properties must be made as part of a holistic process to engender customer delight.

In addition to the four key managerial implications above, the delight properties and corresponding potential routes to delight that emerge from our investigation have implications for employee training programs and overall service design. For example, frontline personnel can be trained to be cognizant of, and to gauge, customers' emotions, interpersonal interactions and problem-solving needs, and potential variations in them across contexts, customers and transactions. Some training programs for sales people already incorporate approaches for accurately assessing the preferences of prospective customers (Khalsa 2015). Offering similar training to all frontline service employees using the delight properties described here as a guide will enable them to gauge individual customers' expectations and hence give them an opportunity to enhance the customers' experience by tailoring service delivery to match those expectations. Managers can also track which delight properties are present / absent in particular contexts, allowing them and their employees to pursue targeted delight strategies and tactics.

Finally, managers could use text analytics approaches utilized in this research to automatically analyze customer delight from different qualitative data sources such as surveys, social media and CRM systems to acquire a holistic view of customer delight. Customers' experience is dynamic and managers need a systematic way to collect, process and analyze customers' data in real time from different touchpoints to obtain insights on various properties of delight.

\section{A PROPOSED FUTURE RESEARCH AGENDA}


Insights from our investigation find the presence of a variety of properties of delight. As a result of this broadened conceptualization and the unique and varied potential routes to delight there is a need for further research to enhance the existing literature.

It is clear from the findings of this research that there is no single delightful experience for a customer. By combining specific properties, managers have the potential to create a multitude of routes to delight. It is recommended that future research (1) identify and explicate these alternative routes for engendering delight through the six properties, (2) develop a general typology based on service context and characteristics, customer segment, etc., that categorizes these routes and stimulates further scholarship on delight, and offers more industry specific insights for managers and 3) determine how these properties translate into short-term and longterm behaviors that are beneficial to the firm (i.e., reviews, referrals, share of spending, retention, etc.).

Although service context was not the focus of this investigation, delightful experiences as described by participants of the study spanned many contexts. In fact, the findings suggest that customers can experience delight even during more ordinary/mundane encounters. Therefore, research is needed to better understand how delight manifests itself in various service contexts, and the influence of the six properties in producing delight across service contexts. For example, are there combinations of specific properties that tend to induce delight in a grocery store setting, and how does this combination differ from other contexts (e.g., financial services, hospitality, air travel, funeral services, etc.)?

Additionally, there is a strong need to understand the role of customer characteristics on the receptiveness and effectiveness of the six properties in inducing customer delight. Empirical 
examination of customer experiences across a broad range of customer characteristics, industries, and countries is needed to develop and distinguish delight.

These questions also have implications regarding changes in a customer's Zone of Tolerance, i.e. "the difference between desired service and the level of service considered adequate" (Zeithaml et al., 1993, pg. 6). Inherent in the zone of tolerance model, customers enter service encounters with different expectation levels and have wider or narrower zones of tolerance. How do initial and repeated delightful experiences that are associated with various properties impact the levels and range of the Zone of Tolerance? Research shows that experience reduces the variability in customers' expectations, and adjusts what customers expect will happen (Rust, Zahorik, and Keiningham 1994). Do delightful experiences also raise customers' minimally acceptable level as well? One might logically presume that the answer to this question is yes_-which would result in a shrinking of the zone of tolerance-but here too we have very little empirical evidence to support this hypothesis.

As the six properties associated with delight uncovered in this investigation are new to the delight literature, there is a strong need for new methods for measuring and monitoring customer delight. While a review of current measures — most of which are based on a narrower conceptualization of delight as extreme satisfaction or a positive emotion — are a useful starting point, a more comprehensive approach that takes into account the broader view uncovered is warranted.

Future research should explore and test new methodological approaches (beyond critical incident techniques that have been the norm to date) that are both ideal and feasible for gauging customer delight. One potentially fruitful research avenue for such an investigation is unstructured data analyses (e.g., text analysis). Customers' comments constitute an excellent 
source for marketers to unearth meaning at high temporal frequency (Tirunillai and Tellis 2014), and to gain insight into customer delight. Due to the volume and unstructured nature of such open-ended consumer-generated content (on customer websites, social media, online reviews, etc.) text mining is well suited to extract customer opinions from unstructured comments and customer satisfaction data (Pang and Lee 2008; Zaki and Neely 2019). These techniques, although well established in information systems and computer science literatures (e.g. Schmunk et al. 2014), are just beginning to be applied in marketing to gain customer insight. Indeed, the approach described here enables text analytics to capture specialized delight vocabulary (e.g., contentment, peace, relief, and sense of achievement) used by the customers. Future research could build upon and refine the text mining approach used in Study 3 and test our approach with bigger datasets and in different contexts such as business to business (B2B) and professional services.

There are many other research techniques that have the potential to augment our understanding of delight (e.g., neuroscience, anthropological research, fuzzy-set qualitative comparative analysis (Fs/QCA), etc.) and are worth exploring. Moreover, given the breadth of customer delight properties uncovered in this investigation, no single method of measuring and monitoring delight may prove adequate. As research into customer delight advances, multiple measurements from different perspectives could yield better understanding. 


\section{REFERENCES}

Aksoy, L. (2013), "How do you measure what you can't define? The current state of loyalty measurement and management", Journal of Service Management, Vol. 24 No. 4, pp. 356381.

Anderson, E.W. and Mittal, V. (2000), "Strengthening the satisfaction-profit chain", Journal of Service Research, Vol. 3 No. 2, pp. 107-120.

Andreassen, T.W., Kristensson, P., Lervik-Olsen, L., Parasuraman, A., McColl-Kennedy, J.R., Edvardsson, B. and Colurcio, M. (2016), "Linking service design to value creation and service research", Journal of Service Management, Vol. 27 No. 1, pp. 21-29.

Arnold, M., Reynolds, K.E., Ponder, N. and Lueg, J.E. (2005), "Customer delight in a retail context: investigating delightful and terrible shopping experiences", Journal of Business Research, Vol. 58 No. 8, pp. 1132-1145.

Ball, J. and Barnes, D.C. (2016), "Gratitude and delight: beyond joy and surprise", Journal of Service Theory and Practice, Vol. 27 No. 1, pp. 250-269.

Barnes, D.C., Beauchamp, M.B. and Webster, C. (2010), "To delight, or not to delight? This is the question service firms must address", The Journal of Marketing Theory and Practice, Vol. 18 No. 3, pp. 275-284.

Barnes, D.C., Ponder, N. and Dugar, K. (2011), "Investigating the key routes to customer delight", The Journal of Marketing Theory and Practice, Vol. 19 No. 4, pp. 359-376.

Barnes, D.C., Collier, J.E., Ponder, N. and Williams, Z. (2013), "Investigating the employee's perspective of customer delight", Journal of Personal Selling \& Sales Management, Vol. 33 No. 1, pp. 91-104.

Barnes, D.C., Collier, J.E., Howe, V. and Douglas, H.K. (2016), "Multiple paths to customer delight: the impact of effort, expertise and tangibles on joy and surprise", Journal of Services Marketing, Vol. 30 No. 3, pp. 277-289.

Barnes, D.C. and Alexandra Krallman (2019), "Customer delight: A review and agenda for research," Journal of Marketing Theory and Practice, Vol. 27 No. 2 , 174-195.

Bartl, C., Gouthier, M.H.J. and Lenker, M. (2013), "Delighting consumers click by click: antecedents and effects of delight online", Journal of Service Research, Vol. 16 No. 3 , pp. 386-399.

Batra, R. Ahuvia, A and Bagozzi R. P. (2012, "Brand Love," Journal of Marketing, Vol. 76 No. 2, pp. 1-16.

Berman, B. (2005), "How to delight your customers", California Management Review, Vol. 48 No. 1, pp. 129-151.

Bitner, M.J. (1992), "Servicescapes: the impact of physical surroundings on customers and employees", Journal of Marketing, Vol. 56 No. 2, pp. 57-71.

Blodgett, J.G., Hill, D.J. and Tax, S.S. (1997), "The effects of distributive, procedural and interactional justice on postcomplaint behavior", Journal of Retailing, Vol. 73 No. 2, pp. 185-210.

Bolton, R.N., McColl-Kennedy, J.R., Cheung, L., Gallan, A., Orsingher, C., Witell, L. and Zaki, M. (2018), "Customer experience challenges: bringing together digital, physical and social realms”, Journal of Service Management, Vol. 29 No. 5, pp. 776-808. 
Bowen, D.E. (2016), "The changing role of employees in service theory and practice: an interdisciplinary view", Human Resource Management Review, Vol. 26 No. 1, pp. 4-13.

Brady, M.K., Voorhees, C.M. and Brusco, M.J. (2012), "Service sweethearting: its antecedents and customer consequences", Journal of Marketing, Vol. 76 No. 2, pp. 81-98.

Braun, V. and Clarke, V. (2006), "Using thematic analysis in psychology", Psychology, Vol. 3 , pp. $77-101$.

Chitturi, R., Raghunathan, R. and Mahajan, V. (2008), "Delight by design: the role of hedonic versus utilitarian benefits", Journal of Marketing, Vol. 72 No. 3, pp. 48-63.

Christensen, C.M., Hall, T., Dillon, K. and Duncan, D.S. (2016), "Know your customers' "jobs to be done", Harvard Business Review, Vol. 9, pp. 54-62.

Colm, L., Ordanini, A. and Parasuraman, A. (2017), "When service customers do not consume in isolation: a typology of customer copresence influence modes (CCIMs)", Journal of Service Research, Vol. 20 No. 3, pp. 223-239.

Cook, L.S., Bowen, D.E., Chase, R.B., Dasu, S., Stewart, D.M. and Tansik, D.A. (2002), "Human issues in service design", Journal of Operations Management, Vol. 20 No. 2, pp. 159-174.

Creswell, J.W. (2013), Qualitative Inquiry and Research Design: Choosing Among Five Approaches, Sage, New York, NY.

Crotts, J.C., Pan, B. and Raschid, A.E. (2008), "Research in brief: a survey method for identifying key drivers of guest delight", International Journal of Contemporary Hospitality Management, Vol. 20 No. 4, pp. 462-70.

Curtin, Steve (2013), Delight Your Customers, AMACOM, New York, NY.

De Keyser, A., Lemon, K.N., Klaus, P. and Keiningham, T.L. (2015), "A framework for understanding and managing the customer experience", working paper [15-121], Marketing Science Institute.

Denegri-Knott, J., Zwick, D. and Schroeder, J.E. (2006), "Mapping consumer power: an integrative framework for marketing and consumer behavior", European Journal of Marketing, Vol 40 No. 9/10, pp. 950-971.

Edelman, D.C. and Singer, M. (2015), "Competing on customer journeys", Harvard Business Review, Vol. 93 No. 11, pp. 88-100.

Estelami, H. (2000), "Competitive and procedural determinants of delight and disappointment in consumer complaint outcomes", Journal of Service Research, Vol. 2 No. 3, pp. 285300.

Field, J.M., Victorino, L., Buell, R.W., Dixon, M.J., Goldstein, S.M., Menor, L.J., Pullman, M.E., Roth, A.V., Secchi, E. and Zhang, J.J. (2018), “Service operations: what's next?", Journal of Service Management, Vol. 29 No.1, pp. 55-97.

Finn, A. (2005), "Reassessing the foundations of customer delight", Journal of Service Research, Vol. 8 No. 2, pp. 103-116.

Finn, A. (2012), "Customer delight distinct construct or zone of nonlinear response to customer satisfaction?", Journal of Service Research, Vol. 15 No. 1, pp. 99-110.

Foxman, A. (2018), "Getting shoppers into stores takes more than inventory", available at: https://www.nytimes.com/2018/10/25/style/getting-shoppers-into-stores.html (accessed 25 October 2018).

Gilbert, D. (2006), Stumbling on Happiness, Vintage Canada, Toronto, Canada.

Goldsmith, K., Cho, E.K. and Dhar, R. (2012), "When guilt begets pleasure: the positive effect of a negative emotion", Journal of Marketing Research, Vol. 49 No. 6, pp. 872- 81. 
Gremler, D.D. (2004), "The critical incident technique in service research", Journal of Service Research, Vol. 7 No. 1, pp. 65-89.

Grönroos, C. (1988), "Service quality: The six criteria of good perceived service", Review of Business, Vol. 9 No. 3, p. 10.

Heskett, J.L., Sasser, W.E. and Schlesinger, L.A. (1997), The Service Profit Chain, The Free Press, New York, NY.

Humphreys, A. and Wang, R.J.H. (2018), "Automated text analysis for consumer research", Journal of Consumer Research, Vol. 44 No. 6, pp. 1274-1306.

Ireland, L. (2011), "Stop surprising \& delighting customers - just solve their problems!", available at: http://www.mpdailyfix.com/stop- surprisingdelighting-customers-just-solve-their-problems/ (accessed 16 July 2016).

Jones, T.O. and Sasser, E. (1995), "Why satisfied customers defect", Harvard Business Review, Vol. 73 (November/December), pp. 88-99.

Kano, K.H., Hinterhuber, H.H., Bailon, F. and Sauerwein, E. (1984), "How to delight your customers", Journal of Product and Brand Management, Vol. 5 No. 2, pp. 6-17.

Keiningham, T.L., Goddard, M.K.M., Vavra, T.G. and Iaci, A.J. (1999), "Customer delight and the bottom line", Marketing Management, Vol. 8 No. 3, pp. 57-63.

Keiningham, T.L., Perkins-Munn, T. and Evans, H. (2003), "The impact of customer satisfaction on share-of-wallet in a business-to-business environment", Journal of Service Research, Vol. 6 No. 1, pp. 37-50.

Keiningham, T.L., Gupta, S., Aksoy, L. and Buoye, A. (2014), "The high price of satisfaction”, MIT Sloan Management Review, Vol. 55 No. 3, pp. 37-46.

Khalsa, G.G. (2015), The Sandler High-Tech Selling System, Sandler Training, Herndon, VA.

Kim, M.G. and Mattila, A.S. (2013), "Does a surprise strategy need words?: the effect of explanations for a surprise strategy on customer delight and expectations", Journal of Services Marketing, Vol. 27 No. 5, pp. 361-370.

Kumar, A., Olshavsky, R.W. and King, M.F. (2001), "Exploring alternative antecedents of customer delight", Journal of Consumer Satisfaction Dissatisfaction and Complaining Behavior, Vol. 14, pp. 14-26.

Kumar, A. and Iyer, R. (2001), "Role of interpersonal factors in delighting customers", Marketing Management Journal, Vol. 11 No. 1, pp. 49-57.

Kwortnik, R.J. and Ross, W.T. (2007), "The role of positive emotions in experiential decisions", International Journal of Research in Marketing, Vol. 24 No. 4, pp. 324-35.

Larivière, B., Keiningham, T.L., Aksoy, L., Yalçin, A., Morgeson III, F.V. and Mithas, S. (2016), "Modeling heterogeneity in the satisfaction, loyalty intention, and shareholder value linkage: a cross-industry analysis at the customer and firm levels", Journal of Marketing Research, Vol. 53 No. 1, pp. 91-109.

Lemon, K.N. and Verhoef, P.C. (2016), "Understanding customer experience throughout the customer journey", Journal of Marketing, Vol. 80 No. 6, pp. 69-96.

L'Oréal Paris USA (2014), "Virtually, makeup app tutorial | makeup genius | L'Oreal,", available at: https://youtu.be/G1z2Od51IsA, (accessed 19 June 2016).

Loureiro, S.M.C. (2010), "Satisfying and delighting the rural tourists", Journal of Travel \& Tourism Marketing, pp. 396-408.

Loureiro, S., Correia, M. and Ribeiro, L. (2014), "Virtual atmosphere: the effect of pleasure, arousal, and delight on word-of-mouth", Journal of Promotion Management, Vol. 20 No. 4, pp. 452-469. 
Magnini, V.P., Crotts, J.C. and Zehrer, A. (2011), "Understanding customer delight: an application of travel blog analysis", Journal of Travel Research, Vol. 50 No. 5, pp. 535545.

Maguire, L. and Geiger, S. (2015), "Emotional timescapes: the temporal perspective and consumption emotions in services", Journal of Services Marketing, Vol. 29 No. 3, pp. 211223.

McColl-Kennedy, J.R., Zaki, M., Lemon, K.N., Urmetzer, F. and Neely, A. (2019), “Gaining customer experience insights that matter", Journal of Service Research, Vol. 22 No. 1, pp. 8-26.

Ngobo, P.V. (1999), "Decreasing returns in customer loyalty: does it really matter to delight the customers?", Advances in Consumer Research, Vol. 26 No. 1, pp. 469-476.

O'Reilly, M., and Parker, N. (2013), "Unsatisfactory saturation: a critical exploration of the notion of saturated sample sizes in qualitative research", Qualitative Research, Vol. 13 No. 2, pp. 190-197.

Oliver, R.L., Rust, R.T. and Varki, S. (1997), "Customer delight: foundations, findings, and managerial insight", Journal of Retailing, Vol. 73 No. 3, pp. 311-336.

Oliver, R.L. (2010), Satisfaction: A Behavioral Perspective on the Consumer, 2nd edition, M.E. Sharpe, Armonk, NY.

Ordenes, F.V., Theodoulidis, B., Burton, J., Gruber, T. and Zaki, M. (2014), "Analyzing Customer Experience Feedback Using Text Mining: A Linguistics-Based Approach", Journal of Service Research, Vol. 17 No. 3, pp. 278-295.

Pang, B. and Lee L. (2008), "Opinion mining and sentiment analysis", Foundations and Trends in Information Retrieval, Vol. 2 No. 1-2, pp. 1-35.

Parasuraman, A. (2013), “Customer delight - more confusion than clarity?", Frontiers in Service Conference, National Taiwan University, Taipei, Taiwan (July 4-7).

Parasuraman, A., Zeithaml, V.A. and Berry, L.L. (1988), "SERVQUAL: a multiple-item scale for measuring consumer perceptions of service quality", Journal of Retailing, Vol. 64 (Spring), pp. 12-40.

Parasuraman, A., Zeithaml, V.A. and Berry. L.L. (1985), "A conceptual model of service quality and its implications for future research", Journal of Marketing, pp. 41- 50.

Patton, M.Q. (2002), "Two decades of developments in qualitative inquiry a personal, experiential perspective", Qualitative Social Work, Vol. 1 No. 3, pp. 261-283.

Plutchik, R. (1980), Emotion: a psychoevolutionary synthesis. Harper Collins College Division, New York.

Rust, R.T. and Zahorik, A.J. (1993), "Customer satisfaction, customer retention and market share”, Journal of Retailing, Vol. 69 No. 2, pp. 193-215.

Rust, R.T. and Cooil, B. (1994), "Reliability measures for qualitative data: theory and implications," Journal of Marketing Research, Vol. 31 No. 1, pp. 1-14.

Rust, R.T., Zahorik, A.J. and Keiningham, T.L. (1995), "Return on quality (ROQ), making service quality financially accountable", Journal of Marketing, Vol. 59 (April), pp. 5870.

Rust, R.T. and Zahorik, A.J. and Keiningham, T.L. (1994), Return on quality: measuring the financial impact of your company's quest for quality, Irwin Professional Publishing, Burr Ridge, IL.

Rust, R.T. and Oliver, R.L. (2000), "Should we delight the customer?", Journal of the Academy of Marketing Science, Vol. 28 No. 1, pp. 86-94. 
Ruth, J.A., Brunel, F.F. and Otnes, C.C. (2002), "Linking thoughts to feelings: investigating cognitive appraisals and consumption emotions in a mixed-emotions context", Journal of the Academy of Marketing Science, Vol. 30 No. 1, pp. 44-58.

Schmunk, S., Höpken, W., Fuchs, M. and Lexhagen, M. (2014), "Sentiment analysis: extracting decision relevant knowledge from UGC”, in Xiang, Z.,Tussyadiah, I. (eds.), Information and Communication Technologies in Tourism, Springer International Publishing, New York, NY, pp. 253-265.

Schneider, B. and Bowen, D.E. (1999), "Understanding customer delight and outrage", Sloan Management Review, Vol. 41 No. 1, pp. 35-45.

Seligman, Martin E.P. and Csikszentmihalyi, M. (2014), Positive Psychology: An Introduction, Springer: Netherlands

Smith, B. (2015), "Intuit's CEO on building a design-driven company", Harvard Business Review, Vol. 93 No. 1, pp. 35-38.

Soars, B. (2009), "Driving sales through shoppers' sense of sound, sight, smell and touch", International Journal of Retail \& Distribution Management, Vol. 37 No. 3, pp. 286-298.

Soscia, I. (2007), "Gratitude, delight, or guilt: the role of consumers' emotions in predicting postconsumption behaviors", Psychology \& Marketing, Vol. 24 No. 10, pp. 871-894.

Spiggle, S. (1994), "Analysis and interpretation of qualitative data in consumer research", Journal of Consumer Research, Vol. 21 No. 3, pp. 491-503.

St-James, Y. and Taylor, S. (2004), "Delight-as-magic: refining the conceptual domain of customer delight", Advances in Consumer Research, Vol. 31 No. 1, pp. 753-58.

Swanson, S.R. and Davis, J.C. (2012), "Delight and outrage in the performing arts: a critical incidence analysis", The Journal of Marketing Theory and Practice, Vol. 20 No. 3, pp. 263-278.

Tirunillai, S. and Tellis, G.J. (2014), "Mining marketing meaning from online chatter: strategic brand analysis of big data using latent dirichlet allocation", Journal of Marketing Research, Vol. 51 No. 4, pp. 463-479.

Valenzuela, A., Mellers, B. and Strebel, J. (2010), "Pleasurable surprises: a cross-cultural study of consumer responses to unexpected incentives", Journal of Consumer Research, Vol. 36 No. 5, pp. 792-805.

Vanhamme, J. (2008), "The surprise-delight relationship revisited in the management of experience", Recherche et Applications en Marketing, Vol. 23 No. 3, pp. 113-138.

Van Vaerenbergh, Y., Varga, D., De Keyser, A., and Orsingher, C. (2019), "The service recovery journey: Conceptualization, integration, and directions for future research," Journal of Service Research, Vol. 22 No. 2, pp. 103-119.

Verma, H.V. (2003), "Customer outrage and delight", Journal of Services Research, Vol. 3 No. 1, pp. 119-133.

Wang, X. (2011), "The effect of unrelated supporting service quality on consumer delight, satisfaction, and repurchase intentions", Journal of Service Research, Vol. 14 No. 2, pp. 149-163.

Westbrook, R.A. (1980), "A rating scale for measuring product/service satisfaction", Journal of Marketing, pp. 68-72.

Wirtz, J., and Lovelock, C. (2016), Services Marketing: People, Technology, Strategy (8th edition), World Scientific, Hackensack, NJ.

Zaki, M. and Neely, A. (2019), “Customer experience analytics: dynamic customer-centric 
model", in Maglio P., Kieliszewski C., Spohrer J., Lyons K., Patrício L., Sawatani Y. (eds) Handbook of Service Science, Volume II. Service Science: Research and Innovations in the Service Economy, Cham, Springer.

Zeithaml, V.A., Berry, L.L. and Parasuraman, A. (1993), "The nature and determinants of customer expectations of service", Journal of the Academy of Marketing Science, Vol. 21 (Winter), pp. 1-12.

Zeithaml, V.A., Parasuraman, A. and Berry, L.L. (1990), Delivering quality service: balancing customer perceptions and expectations, The Free Press, New York, NY. 


\section{APPENDIX 1 Study 1 Invitation/Instructions}

You have been invited to participate in a research study that aims to better understand customer delight through the lens of your day-to-day consumption experiences. Your insights are important to us and we are grateful for your interest in being part of this important work.

Your participation in this study is confidential and your information will be kept secure. Data from this study may provide the basis for academic articles and presentations, but your identity will remain anonymous. Participation is voluntary. If you decide to join the study, you can change your mind at any time.

If you agree to be part of this study, each day, for one week, you will receive a reminder email with a portal to share your observations of customer delight in your day-to-day consumption experiences.

Describe your first customer delight related experience here. Go into as much or as little detail as you would like.

Describe your second customer delight-related experience here. Go into as much or as little detail as you would like.

Would you like to upload a photo, video or other file that corresponds with this story? If yes, please upload it here.

Please note, you will be given space to share your observations of up to five customer delight experiences per day.

Thank you! Please look out for another email reminder tomorrow. We appreciate your participation in this study.

As a participant in this study, you are encouraged to employ all tools and resources at your disposal including written notes, photos, short videos, audio or other collected tangible artifacts to capture and recall your daily consumption experiences. Of course, if you would prefer not to use the online portal to track these experiences, please let me know and I will provide you with a paper journal to capture your insights and observations. This portion of the study is estimated to take no more than 10-20 minutes of your time each day for one week. I am happy to answer any questions that will help you to decide if this study is right for you. Here is my contact information.

Now that you know more about the study, are you ready to sign up? 


\section{TABLE 1: Conceptualizations and Measures of Delight}

\section{References}

Arnold, Reynolds, Ponder, Lueg (2005)

Barnes, Beauchamp,

Webster (2010)

Barnes, Ponder, Dugar (2011)

Barnes, Collier, Ponder, Williams (2013)

Bartl, Gouthier, Lenker (2013)

Chitturi, Raghunathan, Mahajan (2008)

\section{Estelami (2000)}

Finn (2005)

Kim, Mattilla (2013)

\section{Conceptualizations of Delight}

Disconfirmed performance which is highly unlikely based on past experience, and hence is unexpected or surprising (Cognitive) and consisting of a combination of joy and surprise (Affective).

Over-rewarding of the customer as proxy for delight.

Expectations compared to performance, and surprising disconfirmation (Cognitive). Cheerfulness and excitement as a result of receiving hedonic benefits (Affective).

Exceeding expectations to a surprising degree.

Consumers' intense, emotional response following unexpected and positive service performance that exceed the established average service level in an industry.

Exceeding customers' hedonic expectation.

Exceptional levels of satisfaction.

Emotional response, which results from surprising and positive levels of performance.

Positive emotional response to a pleasant surprise combining surprise and joy.

\section{Measures Related to Delight}

Critical Incident Technique: Respondent asked to describe an experience s/he could remember that was absolutely, positively delightful, where delight was explicitly described to the shopper as feelings of both joy or happiness, and surprise.

Satisfaction Scale (Reynolds and Beatty 1999): Displeased me/pleased me, Disgusted with/contented with, Unhappy with/happy with, Frustrating/enjoyable. 7-point Semantic Differential Scale.

Critical Incident Technique: Respondent asked to recall a recent delightful incident and provide a detailed description of the delightful service encounter, to explain expectations prior to the encounter, and to evaluate how delightful encounters are different from satisfactory encounters.

Critical Incident Technique: Respondent (Front Line Employees) asked to provide a recent experience in which they delighted a customer and how delighting the customer made them feel.

Surprise Scale: Surprised, Astonished. 5 point scales (1=Never, 5=Always).Delight Scale (Finn 2005): Delighted, Elated, Gleeful

Single Item Measure: Based on the overall experience of using my current product, I feel ... Delight. 7-point scale ( $1=$ Not at all, 7 = Extremely).

Satisfaction Scale: Response to the positive extreme of the scale (1= Disappointment, $5=$ Delight).

Delight Scale: Delighted, Elated, Gleeful. 5-point scale (1= Never, 5= Always).

Delight Scale (Finn 2005): Delighted, Elated, Gleeful. 5-point scale $(1=$ Never, $5=$ Always). 
Kumar, Olshavsky, King (2001)

Emotional response comprised of joy and surprise although surprise is not always necessary.

Loureiro (2010)

Function of surprising consumption, arousal, and positive affect.

Loureiro, Correia, Ribeiro Function of arousal and pleasure.

(2014)

Magnini, Crotts, Zehrer (2011)

Oliver, Rust, Varki (1997)

Rust, Oliver (2001)

Swanson, Davis (2012)

Verma (2003)

Wang 2011
Positive surprise beyond expectations resulting in arousal, joy, pleasure

A profoundly positive emotional state generally resulting from having one's expectations exceeded to a surprising degree.

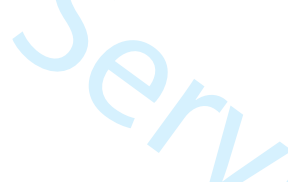

A profoundly positive emotional state generally resulting from having one's expectations exceeded to a surprising degree.

Resultant feeling of how customers are treated or dealt with in a service delivery process.

Experienced joy when the customer is pleasantly surprised in response to an experienced unexpected disconfirmation.

Emotional response when an individual is pleasantly surprised to an unexpected situation of disconfirmation, which is a function of surprising consumption, arousal, and positive affect.
Surprise Scale: Surprise, Expectation, Anticipation. 7-point Semantic Differential Scale. Emotion Scale: 9 emotions (e.g., contented, delighted, thrilled). 6-point scale $(0=$ Did not feel emotion, 5= Experienced emotion very much)

Delight Scale: Enchantment, Delight. Surprising Consumption, Arousal, and Positive Affect: Three items each. 5-point scale.

Emotion Scale: Arousal, Pleasure, Delight. 5-point scale (1=Completely agree, $5=$ Completely disagree)

Text Mining Blog Data for Key Phrases: Pleasantly Surprised, Delightful Surprise, Excellent Surprise, Positive Surprise, Pleasure, Surprise.

Surprising Consumption Items: Compared to expected satisfaction/Expectations, I found Park/Symphony to be... 7- point scale. (1= Much less satisfied/Much worse, $7=$ Much more satisfied/Much better) Categorical coding ( $1=$ Much more satisfied / Much better, $0=$ All other responses). Positive Affect Scale Sample Items: Happy, Delighted, Surprised. 5point scale $(1=$ Never, 5= Always). Arousal Scale: 2 Items. 5-point scale. Single Item Delight Measure: 5-point scale.

Mathematical Model of Customer Delight

(n)

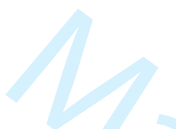

Critical Incident Technique: Respondents asked to think of an experience with the performing arts (e.g., play, concert, etc.) that was particularly delightful.

Critical Incident Technique: Respondents asked to state incidents of service experience when they felt outraged and delighted.

Finn (2005) 8-items; Surprising Consumption (astonished and surprised), Arousal (stimulated, excited, and enthused), and Positive Affect (happy, contented, and pleased). 7-point scale ( $1=$ Never, $7=$ Always). Single Item Measure: Respondents Level of delight. 7-point scale ( $1=$ Not at all, $7=$ Extremely) 


\section{TABLE 2: Sample Comments Supporting the Six Properties of Customer Delight}

\begin{tabular}{|c|c|c|c|c|}
\hline & & Joy & Surprise & Other \\
\hline $\begin{array}{l}\text { Property 1: "Emotions" } \\
\text { Customer delight involves positively } \\
\text { valenced emotions. }\end{array}$ & $\begin{array}{l}\text {-I felt excited, happy, hopeful. I felt together being in there. I can be healthy and it supports what I want for } \\
\text { myself. } \\
\text {-That feeling that you're being valued as a customer. That they like you. I think that there was kind of like, } \\
\text { "Oh, I'm getting a gift because I'm special." So, that feeling of being special. } \\
\text {-It's a similar feeling to a yard sale, that anticipation when you come up to a yard sale, and expect to find a } \\
\text { treasure of hope to find a treasure and that its actually possible to find one there, that's how I feel when I } \\
\text { am in the parking lot. }\end{array}$ & $\mathrm{X}$ & $X$ & $\begin{array}{l}\mathrm{X} \\
\mathrm{X} \\
\mathrm{X}\end{array}$ \\
\hline $\begin{array}{l}\text { Property 2: "Interpersonal" } \\
\text { Customer delight emerges from an } \\
\text { interpersonal interaction. }\end{array}$ & $\begin{array}{l}\text { - He was very patient, helpful and even found a way to save me a few dollars. His attitude change swayed } \\
\text { me from being someone who wouldn't ever deal with that company again to someone who added another } \\
\text { product to my order. } \\
\text {-She was very patient, which was surprising because I feel like very often times people get frustrated when } \\
\text { they're dealing with customer service. } \\
\text { - The delivery guys were actually pretty happy even doing a morning delivery. Like, you know how they } \\
\text { say some people woke up on the wrong side of the bed? These guys were actually lively and cracking jokes } \\
\text { first thing in the morning and seemed to actually enjoy what they were doing. And they were very } \\
\text { professional. Also, I'm a female, I'm there by myself with two guys delivering furniture, but it was a very } \\
\text { comfortable, easy situation. } \\
\bullet \text { The waitress was very patient with my mom. My mom can be a pain in the butt. Very picky. So she didn't } \\
\text { want this or that, but the waitress was very patient, very sweet and took our order. My mom kept saying } \\
\text { "Make sure you don't put this in it" and the waitress was like "okay, that's fine. I won't. I'll make sure you } \\
\text { like that." She was very, very, very attentive. }\end{array}$ & & $X$ & $\mathrm{X}$ \\
\hline $\begin{array}{l}\text { Property 3: "Problem-Solving" } \\
\text { Customer delight emerges from } \\
\text { problem-solving during an } \\
\text { encounter. }\end{array}$ & $\begin{array}{l}\text {-Not just surprise or getting the unexpected, although those are great. It's when you can be surprised, } \\
\text { unexpected and have a problem solved that you did or didn't know you had. That is particularly delightful. } \\
\text { That's like mind blowing almost. } \\
\text { - He was so thorough. I made this one phone call and I knew that everything was completed. He had } \\
\text { crossed the t's and dotted the i's, and made sure that I was going to get everything that I needed when I } \\
\text { needed it. } \\
\text { •So to be able to go there and return something and have it be like, "Oh really, you have a problem? Let } \\
\text { me take care of it." } \\
\text {-I left there with a sense of accomplishment. Success. I have acquired the thing that I set out [to acquire]. } \\
\text { It's like a goal. It's like going hunting. }\end{array}$ & $\mathrm{X}$ & $\mathrm{X}$ & $X$ \\
\hline
\end{tabular}




\begin{tabular}{|c|c|c|c|c|}
\hline $\begin{array}{l}\text { Property 4: "Senses" } \\
\text { Customer delight can be triggered } \\
\text { through various senses. }\end{array}$ & $\begin{array}{l}\text {-They ended up heating it up. Which has completely changed the dynamic of what I was expecting. } \\
\text { Something just warm, buttery, delicious. } \\
\text { - They set the mood. They make sure that there is a really nice ambiance. It's very relaxing so that } \\
\text { definitely contributes to it being delightful. You are completely relaxed, you are listening to nice music, its } \\
\text { smells really good in there. And everyone is just kind of there to make you feel pampered. } \\
\text { - There is always different stuff there and it's all the things I like to buy. There are always surprises in } \\
\text { there, as opposed to other stores where you might go in and see the same things. } \\
\text {-Anything to do with delight I think about my senses. The taste of the food was that I thought was really } \\
\text { good. You know, it was surprising. This was new so therefore it was really kind of exciting. Not new but } \\
\text { how do I explain it? It was different. It was what I was expecting but also different at the same time. }\end{array}$ & & X & $X$ \\
\hline $\begin{array}{l}\text { Property 5: "Timing" } \\
\text { Customer delight can be } \\
\text { instantaneous or can emerge from a } \\
\text { prolonged sequence of events. }\end{array}$ & $\begin{array}{l}\text { - She took the time to take me in and understand what was going on with me in that moment. Rather than } \\
\text { just here and shove me change or the coffee or whatever. She took time to understand my situation too. } \\
\text { - You go through the salad bar and it's just a very nice experience. It's almost relaxing. They don't rush you } \\
\text { there, it's kind of a nice, calming atmosphere compared to going back to work. } \\
\text { - They understand what the customer wants. Where the customer just wants a quick, convenient experience. } \\
\text { - I know it's going to make me really happy. Subway is going to make me happy. The whole experience } \\
\text { from start to finish is exactly the same at every Subway restaurant. I know what I am going to get. There is } \\
\text { no surprises. I can be in and out of there. } \\
\text {-When I go to a hotel and get chocolates on the turndown, I am excited. All that little tiny stuff goes a long } \\
\text { way. When I go back to that hotel, versus another hotel that's the same price, if they're folding down my } \\
\text { bed and putting chocolates on it. Hell yeah! }\end{array}$ & $X$ & & $\begin{array}{l}X \\
X\end{array}$ \\
\hline $\begin{array}{l}\text { Property 6: "Control" } \\
\text { Customer delight is triggered by } \\
\text { perceived control. }\end{array}$ & $\begin{array}{l}\text {-They set up my laptop, my tablet, my cell phone all on the WIFI. They set up my online account for me. } \\
\text { They were very neat with the way they had to drill holes in the wall, wiring, and stuff like that. I } \\
\text { appreciated the fact that they told me what was going to happen up front, and then they made sure that } \\
\text { everything was completed before they left the house. } \\
\text {-When you have food issues and you are in the supermarket, there is a lot of pull in your head when you're } \\
\text { shopping. About what to buy. I sometimes don't have control overeating certain things when I am } \\
\text { somewhere and there in front of me sometimes at the supermarket it's hard. But this was a truly healthy } \\
\text { day. I was not having any problem. I was really excited about eating healthy. It was not a struggle at all, so } \\
\text { that felt delightful. More than delightful, I would like to feel that way all the time. } \\
\text {-I don't want anybody pushing anything on me. When I walk into a store, I don't want, if I want help I'll } \\
\text { ask for it. I don't really want people like down my throat. You know? Trying to talk to me or whatever. }\end{array}$ & $X$ & & $X$ \\
\hline
\end{tabular}




\section{TABLE 3: Potential Routes to Delight}

\begin{tabular}{|c|c|c|c|c|c|c|}
\hline $\begin{array}{l}\text { Property 1: } \\
\text { Emotions }\end{array}$ & $\begin{array}{l}\text { Property 2: } \\
\text { Interpersonal }\end{array}$ & $\begin{array}{l}\text { Property 3: } \\
\text { Problem- } \\
\text { Solving }\end{array}$ & $\begin{array}{l}\text { Property 4: } \\
\text { Timing }\end{array}$ & $\begin{array}{l}\text { Property 5: } \\
\text { Senses }\end{array}$ & $\begin{array}{l}\text { Property 6: } \\
\text { Control }\end{array}$ & $\begin{array}{c}\text { Number of Critical Incidents in Which } \\
\text { Routes Involving the Checked Delight } \\
\text { Properties Emerged }\end{array}$ \\
\hline$\checkmark$ & $\checkmark$ & $\checkmark$ & - & - & - & 71 \\
\hline$\checkmark$ & - & $\checkmark$ & - & - & - & 18 \\
\hline$\checkmark$ & $\checkmark$ & - & - & - & - & 16 \\
\hline$\checkmark$ & $\checkmark$ & $\checkmark$ & $\checkmark$ & - & - & 11 \\
\hline$\checkmark$ & $\checkmark$ & $\checkmark$ & - & $\checkmark$ & - & 6 \\
\hline$\checkmark$ & - & $\checkmark$ & $\checkmark$ & - & - & 5 \\
\hline- & $\checkmark$ & $\checkmark$ & - & - & - & 4 \\
\hline$\checkmark$ & $\checkmark$ & $\checkmark$ & - & 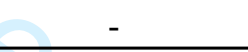 & $\checkmark$ & 4 \\
\hline$\checkmark$ & $\checkmark$ & - & $\checkmark$ & $\checkmark$ & - & 3 \\
\hline$\checkmark$ & $\checkmark$ & $\checkmark$ & $\checkmark$ & $\checkmark$ & - & 3 \\
\hline- & $\checkmark$ & $\checkmark$ & - & $\checkmark$ & - & 2 \\
\hline$\checkmark$ & $\checkmark$ & - & $\checkmark$ & - & - & 2 \\
\hline$\checkmark$ & $\checkmark$ & - & - & $\checkmark$ & - & 2 \\
\hline$\checkmark$ & - & - & - & - & - & 2 \\
\hline- & $\checkmark$ & $\checkmark$ & $\checkmark$ & - & - & 2 \\
\hline- & $\checkmark$ & $\checkmark$ & - & - & 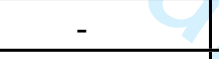 & 0 \\
\hline- & $\checkmark$ & - & $\checkmark$ & - & - & 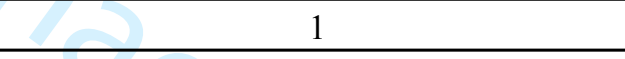 \\
\hline$\checkmark$ & $\checkmark$ & $\checkmark$ & $\checkmark$ & - & $\checkmark$ & $y_{10}$ \\
\hline- & - & - & - & - & - & 100 \\
\hline$\checkmark$ & - & - & - & $\checkmark$ & - & 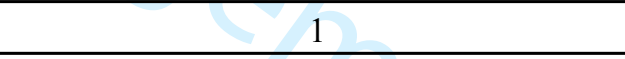 \\
\hline- & $\checkmark$ & - & - & - & - & 1 \\
\hline \multirow[t]{2}{*}{145} & 130 & 128 & 27 & 17 & 5 & 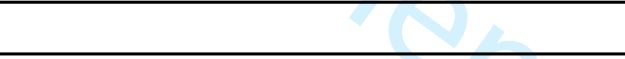 \\
\hline & & & & & & 158 \\
\hline
\end{tabular}


TABLE 4: Other Properties Used When a Specific Property Is Included

\begin{tabular}{|c|c|c|c|c|c|c|}
\hline Emotions & Interpersonal & $\begin{array}{l}\text { Problem- } \\
\text { Solving }\end{array}$ & Timing & Senses & Control & $\mathbf{N}$ \\
\hline $\begin{array}{l}\text { Two Properties } \\
\text { Three }\end{array}$ & $46 \%$ & $51 \%$ & $0 \%$ & $3 \%$ & $0 \%$ & 35 \\
\hline Properties & $94 \%$ & $95 \%$ & $9 \%$ & $3 \%$ & $0 \%$ & 80 \\
\hline Four Properties & $100 \%$ & $88 \%$ & $58 \%$ & $38 \%$ & $17 \%$ & 24 \\
\hline Five Properties & $100 \%$ & $100 \%$ & $100 \%$ & $75 \%$ & $25 \%$ & 4 \\
\hline Interpersonal & Emotions & $\begin{array}{c}\text { Problem- } \\
\text { Solving }\end{array}$ & Timing & Senses & Control & $\mathbf{N}$ \\
\hline $\begin{array}{l}\text { Two Properties } \\
\text { Three }\end{array}$ & $70 \%$ & $26 \%$ & $4 \%$ & $0 \%$ & $0 \%$ & 23 \\
\hline Properties & $95 \%$ & $95 \%$ & $5 \%$ & $5 \%$ & $0 \%$ & 79 \\
\hline Four Properties & $100 \%$ & $88 \%$ & $58 \%$ & $38 \%$ & $17 \%$ & 24 \\
\hline Five Properties & $100 \%$ & $100 \%$ & $100 \%$ & $75 \%$ & $25 \%$ & 4 \\
\hline $\begin{array}{l}\text { Problem- } \\
\text { Solving }\end{array}$ & Emotions & Interpersonal & Timing & Senses & Control & $\mathbf{N}$ \\
\hline $\begin{array}{l}\text { Two Properties } \\
\text { Three }\end{array}$ & $75 \%$ & $25 \%$ & $0 \%$ & $0 \%$ & $0 \%$ & 24 \\
\hline Properties & $95 \%$ & $94 \%$ & $9 \%$ & $3 \%$ & $0 \%$ & 80 \\
\hline Four Properties & $100 \%$ & $100 \%$ & $52 \%$ & $29 \%$ & $19 \%$ & 21 \\
\hline Five Properties & $100 \%$ & $100 \%$ & $100 \%$ & $75 \%$ & $25 \%$ & 4 \\
\hline
\end{tabular}




\begin{tabular}{l|ccccc|c}
\multirow{2}{*}{$\begin{array}{l}\text { Timing } \\
\text { Two Properties }\end{array}$} & Emotions & Interpersonal & $\begin{array}{c}\text { Problem- } \\
\text { Solving }\end{array}$ & Senses & Control & N \\
\cline { 2 - 6 } Three & $0 \%$ & $100 \%$ & $0 \%$ & $0 \%$ & $0 \%$ & 1 \\
Properties & & & & & & \\
Four Properties & $78 \%$ & $44 \%$ & $78 \%$ & $0 \%$ & $0 \%$ & 9 \\
Five Properties & $100 \%$ & $100 \%$ & $79 \%$ & $21 \%$ & $0 \%$ & 14 \\
\cline { 2 - 5 } & $100 \%$ & $100 \%$ & $100 \%$ & $75 \%$ & $25 \%$ & 28 \\
\end{tabular}

\begin{tabular}{|c|c|c|c|c|c|}
\hline Senses & Emotions & Interpersonal & $\begin{array}{l}\text { Problem- } \\
\text { Solving }\end{array}$ & Timing & Control \\
\hline $\begin{array}{l}\text { Two Properties } \\
\text { Three }\end{array}$ & $100 \%$ & $0 \%$ & $0 \%$ & $0 \%$ & $0 \%$ \\
\hline Properties & $50 \%$ & $100 \%$ & $50 \%$ & $0 \%$ & $0 \%$ \\
\hline Four Properties & $100 \%$ & $100 \%$ & $67 \%$ & $33 \%$ & $0 \%$ \\
\hline Five Properties & $100 \%$ & $100 \%$ & $100 \%$ & $100 \%$ & $0 \%$ \\
\hline
\end{tabular}

\begin{tabular}{|c|c|c|c|c|c|}
\hline Control & Emotions & Interpersonal & Solving & Timing & Senses \\
\hline $\begin{array}{l}\text { Two Properties } \\
\text { Three }\end{array}$ & $0 \%$ & $0 \%$ & $0 \%$ & $0 \%$ & $0 \%$ \\
\hline Properties & $0 \%$ & $0 \%$ & $0 \%$ & $0 \%$ & $0 \%$ \\
\hline Four Properties & $100 \%$ & $100 \%$ & $100 \%$ & $0 \%$ & $0 \%$ \\
\hline Five Properties & $100 \%$ & $100 \%$ & $100 \%$ & $100 \%$ & $0 \%$ \\
\hline
\end{tabular}




\section{FIGURE 1: Number of Properties Associated with Delight}

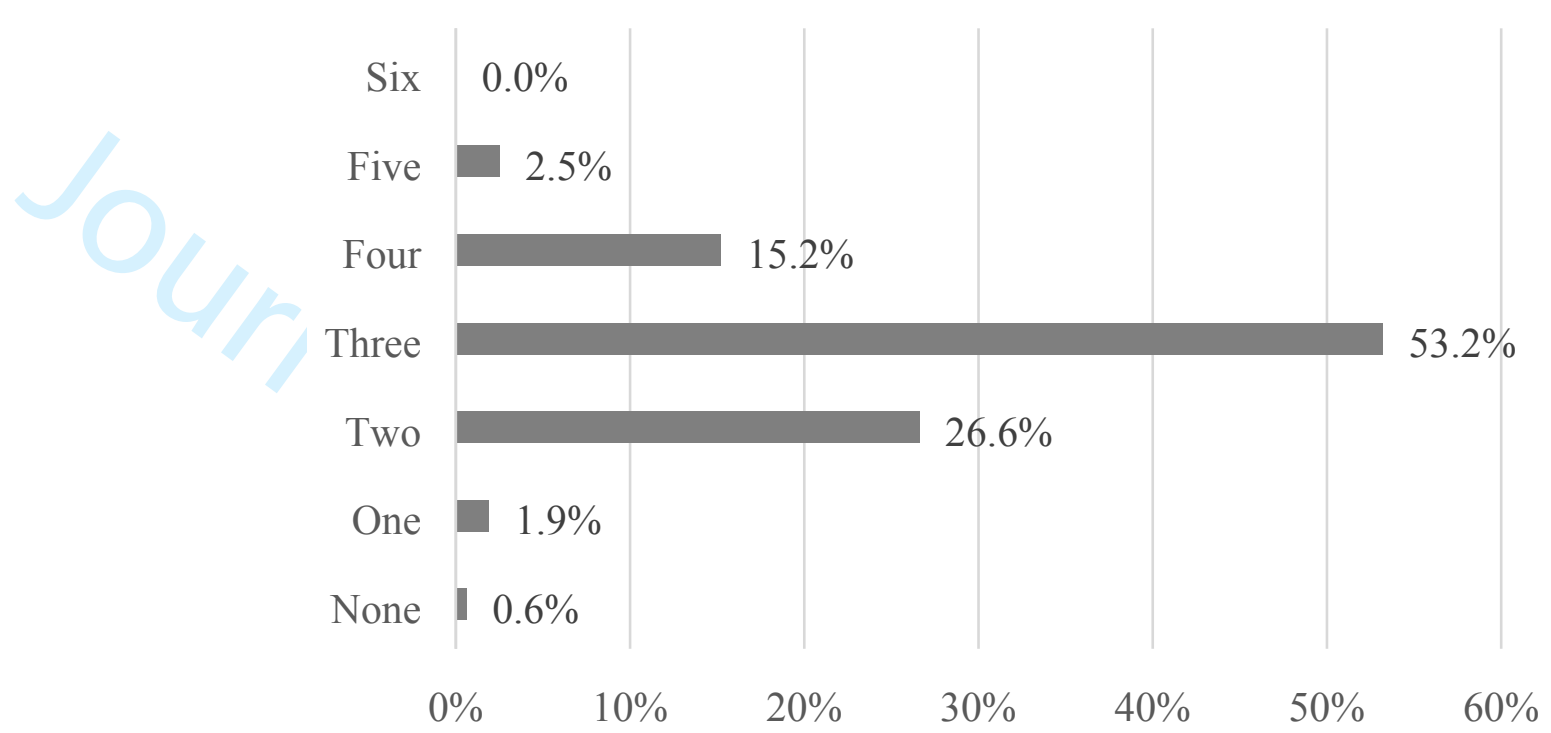


FIGURE 2: Number of Total Ingredients When a Specific Property Is Included

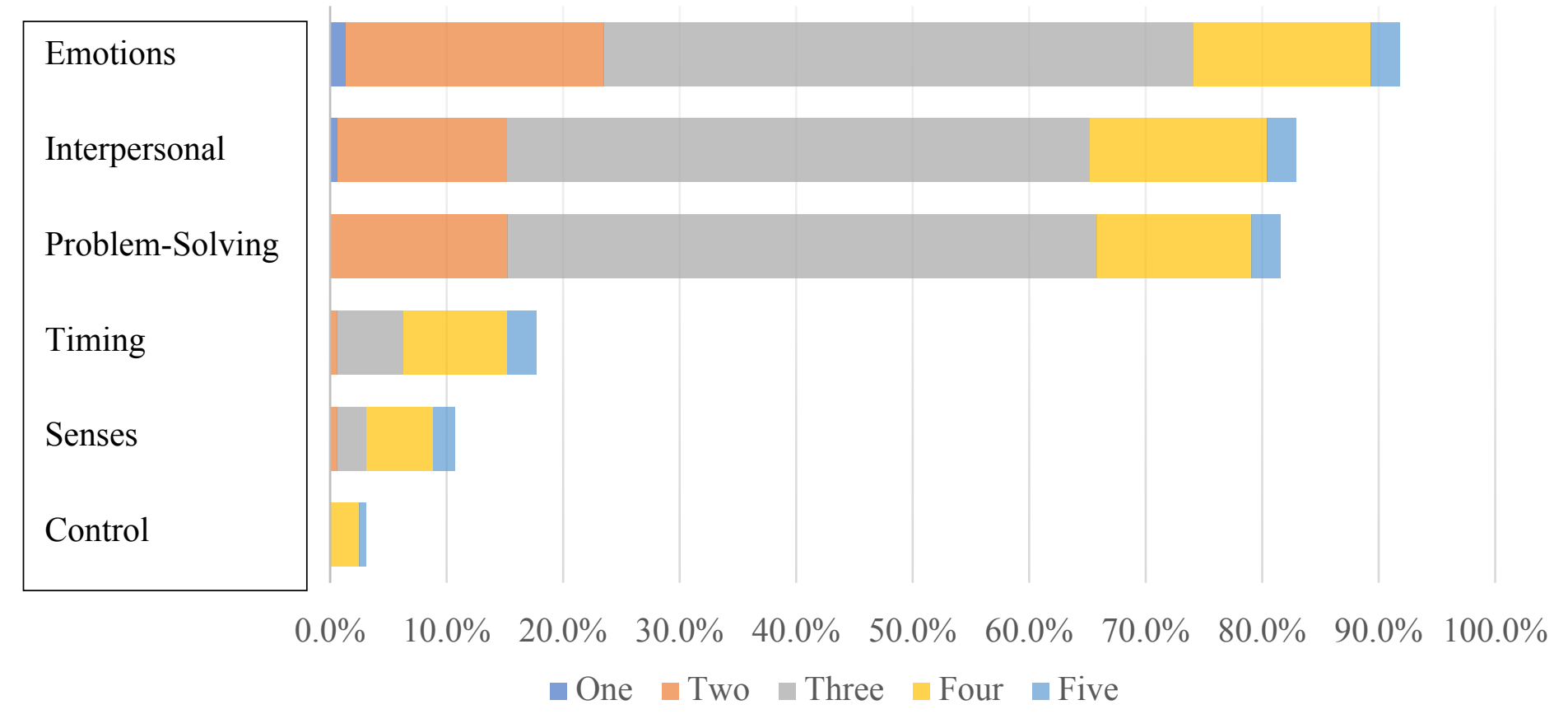

\begin{tabular}{lrrrrrr} 
& \multicolumn{1}{l}{ One } & Two & Three & Four & Five & TOTAL \\
Emotions & $1.3 \%$ & $22.2 \%$ & $50.6 \%$ & $15.2 \%$ & $2.5 \%$ & $91.8 \%$ \\
Interpersonal & $0.6 \%$ & $14.6 \%$ & $50.0 \%$ & $15.2 \%$ & $2.5 \%$ & $82.9 \%$ \\
Problem-Solving & $0.0 \%$ & $15.2 \%$ & $50.6 \%$ & $13.3 \%$ & $2.5 \%$ & $81.6 \%$ \\
Timing & $0.0 \%$ & $0.6 \%$ & $5.7 \%$ & $8.9 \%$ & $2.5 \%$ & $17.7 \%$ \\
Senses & $0.0 \%$ & $0.6 \%$ & $2.5 \%$ & $5.7 \%$ & $1.9 \%$ & $10.7 \%$ \\
Control & $0.0 \%$ & $0.0 \%$ & $0.0 \%$ & $2.5 \%$ & $0.6 \%$ & $3.1 \%$
\end{tabular}

